\title{
PENGARUH RELATIONSHIP MARKETING DAN KEPUASAN PELANGGAN TERHADAP LOYALITAS PELANGGAN INDIHOME PADA PT. TELKOM DATEL SINGARAJA
}

\author{
P. Dibia Atmaja ${ }^{1}$, N. Nyoman Yulianthini ${ }^{2}$ \\ 1,2Jurusan Manajemen, Universitas Pendidikan Ganesha, Singaraja \\ e-mail: dibiiaatmaja35@gmail.com,ninymyulianthini@gmail.com
}

\begin{abstract}
Abstrak
Penelitian ini bertujuan untuk menguji pengaruh (1) relationship marketing tehadap loyalitas pelanggan, (2) kepuasan pelanggan terhadap loyalitas pelanggan, (3) relationship marketing terhadap kepuasan pelanggan, (4) relationship marketing tehadap loyalitas pelanggan melalui kepuasan pelanggan Indihome pada PT Telkom Datel Singaraja. Subjek dari penelitian ini yaitu pelanggan Indihome pada PT. Telkom Datel Singaraja. Objek penelitian ini berfokus pada relationship marketing, kepuasan pelanggan dan loyalitas pelanggan. Jumlah sampel dalam penelitian ini sebanyak 100 orang. Teknik pengumpulan data menggunakan teknik observasi, pencatatan dokumen, dan kuesioner yang dianalisis menggunakan analisis jalur. Dari hasil penelitian menunjukan bahwa, (1) relationship marketing berpengaruh positif dan signifikan terhadap loyalitas pelanggan, (2) kepuasan pelanggan berpengaruh positif dan signifikan terhadap loyalitas pelanggan, (3) relationship marketing berpengaruh positif dan signifikan terhadap kepuasan pelanggan, (4) relationship marketing berpengaruh positif dan signifikan terhadap loyalitas pelanggan melalui kepuasan pelanggan Indihome pada PT Telkom Datel Singaraja
\end{abstract}

Kata Kunci: kepuasan pelanggan, loyalitas pelanggan, relationship marketing

\begin{abstract}
This study aims to examine the effect of (1) relationship marketing on customer loyalty, (2) customer satisfaction on customer loyalty, (3) relationship marketing on customer satisfaction, (4) relationship marketing on customer loyalty through customer satisfaction Indihome at PT Telkom Datel Singaraja. . The subjects of this study were Indihome customers at PT. Telkom Datel Singaraja. The object of this research focuses on relationship marketing, customer satisfaction and customer loyalty. The number of samples in this study were 100 people. Data collection techniques using observation techniques, document recording, and questionnaires were analyzed using path analysis. The research results show that, (1) relationship marketing has a positive and significant effect on customer loyalty, (2) customer satisfaction has a positive and significant effect on customer loyalty, (3) relationship marketing has a positive and significant effect on customer satisfaction, (4) relationship marketing positive and significant effect on customer loyalty through customer satisfaction Indihome at PT Telkom Datel Singaraja.
\end{abstract}

Keywords: customer loyalty, customer satisfaction, relationship marketing

\section{Pendahuluan}

Pada era globalisasi sekarang ini, telekomunikasi memegang peranan yang sangat penting dan strategis dalam kehidupan manusia. Hal ini mengindikasian pengaruh dari dampak globalisasi. Aktivitas yang banyak digunakan seperti pendidikan, industri, komersial dan perkantoran relative banyak menggunakan kemudahan ini. Melalui communication techoolgy, manusia dengan mudah menukar infomasi dari jarak juh dengan waktu yang singkat dan efisien.

Hasil studi dari Polling Indonesia dan Asosiasi Penyelenggara Jasa Internet Indonesia ( APJII), di tahun 2018 total pemakai internet yang ada di Indonesia dengan jumlah 171,17 juta jiwa. Jumlah angka ini sama dengan $64,8 \%$ dari keseluruhan penduduk yang ada di Indonesia. Berbanding dengan tahun 2017, diperoleh peningkatan pemakai internet yang mencapai hingga 27,92 juta jiwa atau tumbuh sekitar 10,12\% (sumber: https://www.cnbcindonesia.com/).

Perusahaan PT.Telekomunikasi Indonesia (Tbk) adalah naungan dari kementerian BUMN yang beroperasi pada bidang telekomunkasi dan juga pelaku telekomunikasi dan jaringan raksasa yang ada di Indonesia. TIMES (Telecommunication, Information, Media Edutainment \& 
Services) menggambarkan portofolio bisnis yang besar dan didongkrak dengan visi misi yang kuat serta memiliki profesionalisme dalam bisnis. PT.Telkom Indonesia (Tbk) percaya bisa mewujudkan segala kebutuhan yang di perlukan masyarakat seluruh Indonesia khususnya dalam hal telekomunikasi dan jaringan.

Dari banyaknya ISP (Internet Service Provider) yang ada, perusahaan yang gencar menawarkan pelayanan internetnya adalah Indihome. Indihome merupakan layanan bundling triple play. Sebelum Indihome ada, Telkom Indonesia memiliki produk internet yang pertama bernama Speedy, yang sekarang di rebranding menjadi Indihome. Adapun perbedaan dari kedua produk ini adalah speedy dengan menggunakan kabel cooper, sedangkan Indihome sudah memakai fiber optic cable. Hal ini Indihome mampu mengungguli speedy karena Indihome sendiri memiliki kecepatan internet hingga $100 \mathrm{Mbps}$ serta tahan dari pergantian cuaca dan musim. Sejak diluncurkannya dari tahun 2015, data menunjukkan Indihome selalu menjadi Top Brands Award dari tahun 2016 sampai 2019.

Namun menjadi Top Brands, produk Indihome tidak diimbangi dengan presentase pengguna yang kian menaik. Perolehan indihome mengalami fluktuasi angka penggunaan. Pada tahun 2017, Indihome mengalami kenaikan dengan presentase 2,2\%. Hal ini tidak menjadikan Indihome selalu mengalami kenaikan. Terbukti tahun 2018, penurunan dengan presentase $8,2 \%$. Dan di tahun 2019 juga mengalami penurunan 2,3\%. Sedangkan pada ISP (Internet Service Provider) lainnya tengah mengalami peningkatan setiap tahunnya.

PT. Telkom Tbk kantor cabang Bali Utara yang beralamat di jalan Jl. Letkol Wisnu No.2, Banjar Jawa, Kec. Buleleng, Kabupaten Buleleng, Bali 8111. Kantor Telkom terbagi menjadi 2 wilayah yang sangat luas salah satunya Witel (Wilayah Telekomunikasi) dan Datel (Daerah Telekomunikasi). Telkom Witel Singaraja menjaring 3 wilayah kabupaten yang ada di Bali, seperti wilayah Singaraja, wilayah Gianyar, dan wilayah Tabanan. Sedangkan Telkom Datel Singaraja hanya yang berada di sekitar Singaraja, seperti STO Kota Singaraja, STO Lovina, dan STO Seririt. Dalam penelitian ini, peneliti hanya memfokuskan pada Datel Singaraja yang dimana terbagi menjadi sto Singaraja, Lovina, dan Seririt.

PT. Telkom Tbk merupakan penyedia jasa internet yang menyediakan berbagai macam kecepatan dan fasilitas internet. Diawal keberadaan penyedia jasa internet di Kota Singaraja, produk dari Telkom sangatlah diminati di kalangan masyarakat. Sebelum adanya Indihome, produk speedy dari PT. Telkom lebih dulu hadir hingga sekarang kini berganti menggunakan produk Indihome dengan teknologi fiber optic. Seiring berjalannya waktu, produk Indihome telah mengalami fluktuasi penjualan yang dilihat dalam tabel.

Tabel 2

Pengguna Indihome pada Datel Singaraja tahun 2019

\begin{tabular}{|c|c|}
\hline Bulan & Penggunan Indihome (orang) \\
\hline 1 & 413 \\
\hline 2 & 350 \\
\hline 3 & 339 \\
\hline 4 & 416 \\
\hline 5 & 572 \\
\hline 6 & 334 \\
\hline 7 & 311 \\
\hline 8 & 289 \\
\hline 9 & 404 \\
\hline 10 & 585 \\
\hline 11 & 685 \\
\hline 12 & 425 \\
\hline Total & 5.123 \\
\hline
\end{tabular}

(Sumber. Data Diolah)

Berdasarkan hasil observasi awal yang diperoleh penulis dari data PT. Telkom kantor cabang Bali Utara pada tahun 2019 menunjukkan bahwa jumlah penggunaan mengalami 
fluktuasi. Hal tersebut dapat dilihat dari naik turunnya jumlah pelanggan pada tahun 2019. Hal ini mengindikasikan bahwa loyalitas pelanggan mengalami penurunan dalam menggunakan produk Indihome dari PT. Telkom Indonesia. Dapat dikatakan bahwa belum optimalnya pihak manajemen dalam mengelola perusahaannya, sehingga manajemen harus mengevaluasi layanan yang diberikan ke pelanggan. Menjalin hubungan baik dengan pelanggan tentunya akan berdampak baik untuk perusahaan. Dampak yang dirasakan tidak semata hubungan dalam jangka pendek, namun bisa menjamin jangka panjang atau kesetiaan pelanggan dalam menggunakan produk Indihome.

Loyalitas pelanggan yakni pengukuran kesetiaan dari konsumen dalam menggunakan suatu ptoduk atau merek pada waktu tertentu disituasi dimana banyak pilihan produk ataupun jasa yang dapat untuk memenuhi kebutuhannya(Nugroho, 2005: 11). Apabila kenyataan kinerja tidak sesuai harapan pelanggan maka akan terjadi ketidaksesuaian terhadap pelayanan yang diberikan oleh perusahaan.

Prosedur yang akan dilakukan oleh perusahaan dalam mewujudkan loyalitas pelanggan yaitu dengan mempererat relasi ke konsumen atau sering disebut relationship marketing. Menurut definisi Keegan, et al (dalam Hindarto, 2013: 41), menjelaskan relationship marketing merupakan usaha yang dilakukan untuk meningkatkan relasi jangka panjang perusahaan dan memberikan kepuasan yang maksimal kepada pelanggan. Penelitian oleh Farizka (2011), membuktikan bahwa hubungan pemasaran sangat berdampak akan kepuasan konsumen dan berdampak akan loyalitas konsumen baik secara langsung ataupun melalui kepuasan pelanggan. Kajian lainnya dari Romero, et al (2014) juga menunjukkan kalau hubungan pemasaran berdampak dengan kepuasan dan kepercayaan pelanggan terhadap komitmen konsumen. Hasilnya, dari desaing hubungan pemasaran akan berimplikasi terhadap kepuasan dan loyalitas konsumen.

Kepuasan pelanggan adalah respon berupa perasaan puas yang timbul karena pengalaman mengkonsumsi suatu produk atau layanan atau sebagian kecil dari pengalaman itu (Buttle, 2004: 29). Dari banyaknya perusahaan yang tidak mencapai target dari penjualan, dikarenakan karena belum maksimal menerapkan strategi kepuasan konsumen, sehingga kesetiaan pelanggan terhadap barang atau jasa yang ditawarkan perusahaan sulit untuk dipertahankan. Untuk mempertahankan pelanggan yang sudah ada, pihak perusahaan atau pengusaha dituntut untuk selalu tanggap terhadap apa yang diinginkan pelanggan. Kajian yang dilakukan oleh Widjaja (2016) menunjukkan kepuasan konsumen berdampak signifikan terhadap loyalitas konsumen, sehingga ini didasarkan dari kuesioner yang telah disebar berdasarkan analisa deskriptif dimensi kepuasan konsumen dan loyalitas konsumen menunjukkan kesetujuan konsumen akan tercipta kepuasan pelanggaan dan loyalitas pelaggan pada perusahaan tersebut. Hasil kajian dari Husodho (2015) menunjukkan variabel dari kepuasan konsumen mempunyai pengaruh ke loylitas planggan. Sedangkan penelitan dari Martini (2013) membuktikan kepuasan planggan tidak berdampak signifikan ke loyalitas pelanggan. Adapun tujuan dari kajian ini yaitu untuk menguji (1) efek dari hubungan pemasaran terhadap loyalitas pelanggan Indihome pada PT. Telkom Datel Singaraja (2) pengaruh kpuasan konsumen ke loylitas konsumen Indihome dari PT. Telkom Datel Singaraja, (3) pengaruh relationship marketing kepada kpuasan konsumen dari produk Indihome pada PT. Telkom Datel Singaraja dan (4) pengaruh relationship marketing terhadap loyalitas pelanggan Indihome pada PT. Telkom Datel Singaraja melalui kepuasan pelanggan.

\section{Metode}

Jenis penelitian yang digunakan adalah penelitian kuantitatif. Model desain penelitian ini adalah desain penelitian kausal. Kajian yang akan digunakan untuk mengetahui pengaruh relationship marketing dan kepuasan pelanggan terhadap loyalitas pelanggan pada pengguna Indihome PT. Telkom Datel Singaraja. Tahapan dalam desain penelitian kuantitatif kausal terdiri dari (1) merumuskan masalah, (2) mengkaji teori, (3) merumuskan hipotesis, (4) mengumpulkan data, (5) mengolah data, dan (6) menarik kesimpulan. Dalam mencari pengaruh kualitas pelayanan dan harga terhadap kepuasan pelanggan digunakan analisis jalur. 
Subjek dalam penelitian ini adalah perusahaan penyedia jaringan PT. Telkom Tbk Datel Singaraja. Sedangkan yang menjadi objek pada kajian ini yaitu relatonship marketing sebagai $\mathrm{X}_{1}$, kepuasan konsumen sebagai $\mathrm{X}_{2}$, dan loyalitas konsumen sebagai $\mathrm{Y}$. Penelitian ini yakni penelitian sampel karena dalam penelitian ini terdapat populasi yang terlalu banyak. Teknik sampel pada kajain ini menggunakan tekhnik sampel non-probability menggunakan metode purposive sampling, yaitu pengambilan sampel yang dipilih berdasarkan dengan kriteria yang telah ditentukan. Kriteria-kriteria yang telah ditentukan adalah pelanggan yang berlangganan atau menjadi pelanggan dari produk Indihome lebih dari tiga bulan. Ferdinand (2002) menyatakan bahwa dalam melakukan pengukuran sampel tergantung dengan jumlah indikator dikalikan lima sampai sepuluh. Dalam penelitian ini menggunakan 20 indikator sehingga banyaknya responden yang diambil sebagai sampel minimal dalam penelitian ini adalah $20 \times 5=$ 100 dan maksimal sampel yang bisa pakai pada kajian ini yaitu $20 \times 10=200$. Akan tetapi di kajian ini digunakan sampel yang berjumlah 100 responden.

Untuk memenuhi hasil kajian, penulis melaksanakan pengumpulan data dari sumber data tertulis maupun tidak tertulis yakni dengan langkah (1) Metode obsevasi, Sutrino Hadi (dalam Sugiyono, 2007: 139) mengutarakan observasi yakni proses yang berhimpunan, dimana suatu proses yang tersusun dari berbagai proses biologis dan psikhologis. Metode ini digunakan pada saat survei pendahuluan yaitu untuk mengetahui kondisi perusahaan dari segi penggunaan Indihome dan luas wilayah PT. Telkom datel Singaraja, (2) Pencatatan dokumentasi, dokumen merupakan catatan peristiwa yang sudah berlalu. Dokumen biasanya berbentuk tulisan, gambar atau karya-karya monumental dari seseorang (Sugiyono, 2014: 240). Pada penelitian ini penulis melakukan dengan pengamatan berkas-berkas yang disimpan pada PT. Telkom Indonesia kantor area Bali Utara. Data yang diperoleh melalui dokumentasi berupa jumlah pelanggan setiap bulannya pada tahun 2019, (3) Metode kuesioner. Jenis kuesioner yang dipergunakan pada kajian ini yakni kuesioner berstruktur (angket tertutup), dengan kemungkinan jawaban pernyataan yang telah disiapkan dalam bentuk pilihan. Responden tidak perlu lagi memberikan tambahan jawaban, responden hanya tinggal memilih alternatif dari lima atau pernyataan yang sudah tersedia, yang nantinya dapat memudahkan penelitian dalam mengelola dan menganalisis data. Skala yang banyak dipergunakan dalam penyusunan angket adalah skala likert. Skala likert merupakan skala yang berisi lima tingkat jawaban yang disusun dalam bentuk suatu pernyataan.

Kuesioner dalam suatu penelitian ini mesti melengkapi syarta dari validitas dan reliabilitas. Dalam kajian ini, pengecekan alat-alat dilakukan agar dapat memperoleh keakuratan data. Dalam uji validitas, kuesioner dinyatakan valid apabila kuesioner mampu untuk mengungkapkan sesuatu yang diukur oleh kuesioner tersebut. Sebelum digunakan sebagai alat mengumpulkan data harus diuji cobakan terlebih dahulu. Uji coba tersebut dilakukan terhadap responden diluar sampel. Menurut Sugiyono (2007) instrument dikatakan valid apabila koefisien korelasi antar butir lebih besar dari 0,30 dengan tingkat kesalahan alpha 0,05. Kriteria pengujian dilihat dari item instrumen dikatakan valid apabila $p$-value lebih kecil dari alpha 0,05, sedangkan item instrument dikatakan tidak valid apabila $p$-value lebih besar dari alpha 0,05. Untuk mengetahui reliabelnya suatu data maka harus diuji reliabitasnya terlebih dahulu. Suatu variabel dinyatakan reliabel apabila memberikan nilai Croncbach Alpha lebih besar dari 0.60. Pengujian reliabilitas dalam penelitian ini menggunakan bantuan program Statistical Package for Social Science (SPSS) 22.0.

Analisis data pada kajian ini memakai path analysis, merupakan analisis yang dipakai untuk menghitung pola hubungan tidak langsung dan langsung. Path analysis biasanya dipakai untuk menguji model hubungan antar faktor dari sebab akibat. Selain itu, path analysis dipergunakan untuk memahami besarnya hasil dari jumlah pengaruh langsung dan tidak langsung variable relationship marketing dan kepuasan pelanggan ke loyalitas pelanggan produk Indihome pada PT. Telkom Tbk Datel Singaraja.

\section{Hasil Dan Pembahasan}


Berdasarkan hasil perhitungan uji statistik analisis jalur menggunakan program SPSS 22.0 for windows OS, didapat total $\mathrm{Pyx}_{1}=0,617$ dengan $p$-value $=0,000$ lebih kecil dari alpha 0,05 sehingga keputusannya adalah menolak Ho. Hal ini artinya relationship marketing $\left(\mathrm{X}_{1}\right)$ berdampak positif dan signifikan ke loyalitas konsumen Indihome PT. Telkom Indonesia Tbk Datel Singaraja. Pada Tabel 4.4 menunjukkan sumbangan pengaruh langsung $X_{1}$ terhadap $Y$ sebesar $61,7 \%$ sehingga besar sumbangan pengaruh hubungan pemasaran sebagai $X_{1}$ ke loyalitas pelanggan secara total yaitu 0,833 atau $83,3 \%$.

Berdasarkan hasil perhitungan uji statistik analisis jalur menggunakan program SPSS 22.0 for windows OS, didapatkan hasil $\mathrm{Pyx}_{2}=0,366$ dengan $p$-value $=0,000$ lebih kecil dari alpha 0,05 sehingga keputusannya adalah menolak Ho. Hal ini mengindikasikan bahwa kepuasan konsumen $\left(\mathrm{X}_{2}\right)$ memiliki pengaruh secara positif dan signifikan ke loyalitas pelanggan Indihome di PT. Telkom Indonesia Tbk Datel Singaraja. Pada Tabel 4.4 menunjukkan sumbangan pengaruh langsung kepuasan pelanggan $\left(\mathrm{X}_{2}\right)$ terhadap loyalitas pelanggan $(\mathrm{Y})$ sebesar $36,6 \%$.

Berdasarkan hasil perhitungan uji statistik analisis jalur menggunakan program SPSS 22.0 for windows OS, didapatkan dengan hasil $\mathrm{Px}_{2} \mathrm{x}_{1}=0,959$ dengan $p$-value=0,000 lebih kecil dari alpha 0,05 sehingga keputusannya adalah menolak Ho. Ini artinya relationship marketing $\left(\mathrm{X}_{1}\right)$ memiliki pengaruh secara positif dan signifikan terhadap kepuasan konsumen $\left(X_{2}\right)$ Indihome di PT. Telkom Indonesia Tbk Datel Singaraja. Besar sumbangan pengaruh relationship marketing $\left(X_{1}\right)$ terhadap kepuasan pelanggan $\left(X_{2}\right)$ adalah $95,9 \%$.

Berdasarkan perhitungan dari uji statistik analisis jalur yang ada pada program SPSS 22.0 for windows, di tabel 3 diperoleh hasil $\mathrm{Px}_{2} \mathrm{x}_{1}=0,959$ dan $\mathrm{Pyx}_{2}=0,366$ dengan $p$-value $=0,000$ lebih kecil dari alpha 0,05 sehingga sumbangan yang tidak langsung relationship marketing $\left(X_{1}\right)$ ke loyalitas konsumen $(\mathrm{Y})$ melalui kepuasan konsumen $\left(\mathrm{X}_{2}\right)$ didapat dari pengalian $\mathrm{Px}_{2} \mathrm{X}_{1}$. $\mathrm{Pyx}_{2}$ sehingga hasilnya sebesar 0,350 atau $35,0 \%$.

Struktur hubungan pada penelitian ini nampak di Gambar 1.

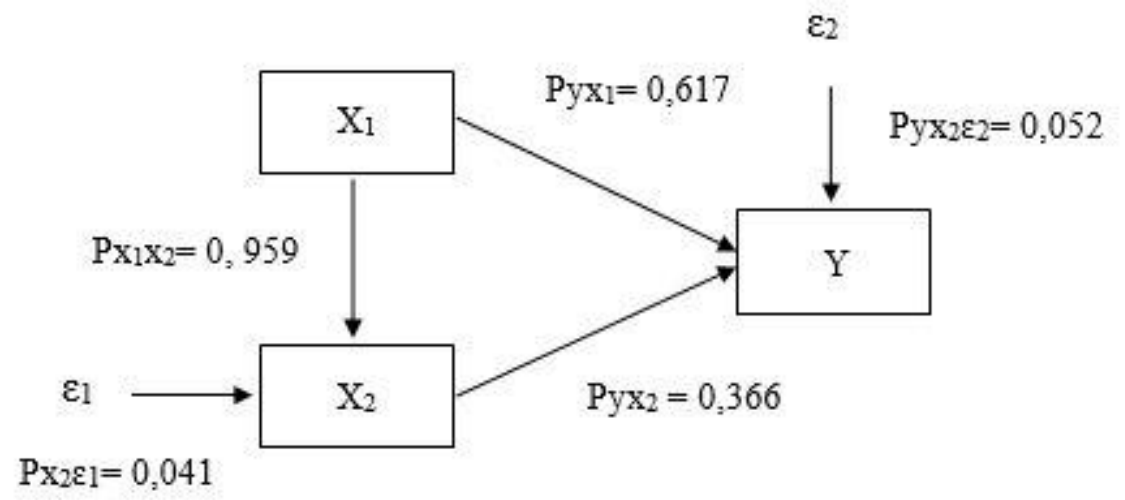

Gambar 1.

Struktur hubungan pengruh relationship marketing $\left(\mathrm{X}_{1}\right)$ dan kepuasan pelanggan $\left(\mathrm{X}_{1}\right) \mathrm{ke}$ loyalitas pelanggan ( $\mathrm{Y}$ ) Indihome pada PT. Telkom Indonesia Tbk DatelSingaraja

Berdasarkan penelitian yanng dilakukan, maka diperoleh temuan bahwa variabel dari $X_{1}$ berpengaruh ke variabel $\mathrm{Y}$. Untuk itu, sejalan dengan konsep yang disampaikan dari Hasan (2013:149) menjelaskan hal terpenting dalam loyalatis yakni usaha untuk membangun hubungan yang baik, tentunya hubungan jangka panjang dengan konsumen (relationship marketing). Anggapannya ialah relationship marketing mampu menjalin relasi yang baik akan berpengaruh terhadap keuntungan perusahaan maupun konsumen dalam membangun bisnis ulang (repeat business) serta membangun customer loyalty. Teori ini searah dengan kajian yang sudah dilakukan oleh Widjaja (2016) mengenai relationship marketing kepada customer loyalty di PT. 
Fuboru Indonesia yang mendapatkan hasil bhawa relationship marketing berpengaruh secara signifikan terhadap loyalitas pelanggan, dimana dalam meningkatkan kesetiaan pelanggan dalam berbagai hal. Relationship marketing menumbuhkan kesetiaan pelanggan dengan memberikan perlakuan yang baik dan memuaskan sehingga pelanggan melakukan pembelian ulang dan melakukan word of mouth. Relationship marketing memberikan dampak jangka panjang sehingga menimbulkan loyalitas pelanggan. Hal tersebut sependapat dengan hasil penelitian yang diperoleh. PT. Telkom Indonesia Tbk Datel Singaraja mengalami fluktuasi angka penggunaan sehingga diperlukan peningkatan dalam hal loyalitas pelanggan. Jika dilihat dari sisi relationship marketing, pelanggan merasa kurang puas dalam hal penanganan keluhan dari pihak perusahaan karena pelanggan harus menunggu beberapa hari untuk penyelesaian tersebut. Disamping itu, kenaikan harga untuk penawaran layanan internet cenderung lebih mahal daripada pesaing sehingga pelanggan ada yang beralih dan memilih yang lebih murah namun mendapatkan kualitas yang sama. Oleh karena itu perusahaan perlu melakukan perbaikan dan evaluasi terkait relationship marketing sehingga pelanggan merasa lebih puas dan merekomendasikan kepada orang-orang terdekat. Hal tersebut memberikan hubungan jangka panjang sehingga pelanggan setia menggunakan layanan internet dari Indihome. Hal ini memberikan implikasi bahwa Relationship marketing dalam waktu yang lama dan pelanggan merasa nyaman maka hal tersebut dapat meningkatkan loyalitas pelanggan. Perusahaan perlu mengupayakan terjadinya loyalitas pelanggan untuk keberlangsungan pelanggan. Upaya yang telah dilakukan oleh perusahaan masih belum optimal sehingga perlu dilakukan pengoptimalan dalam melaksanakan relationship marketing. Upaya peningkatan yang bisa dilakukan diantaranya mengevaluasi keluhan pelanggan setiap seminggu sekali, memberikan penawaran yang terjangkau, meningkatkan profesionalisme dalam pelayanan jangka panjang kepada konsumen.

Hasil penelitian selanjutnya adalah variabel dari customer satisfaction $\left(\mathrm{X}_{2}\right)$ berpengaruh positif dan signifikan terhadap customer loyalty(Y) Indihome PT. Telkom Indonesia Tbk Datel Singaraja. Hasil yang didapat searah dari yang disampaikan dari Hasan (2013: 125) berpendapat jika dampak dari pada kepuasan dan dampak dari ketidakpuasan pelanggan kepada suatu brand yang kian bertambah secara bertahap diluar dari adanya stigma product quality, maka customer satisfaction akan berdampak pada customer loyalty, konsumen tidak hanya membeli ulang suatu produk tetapi mampu memiliki tanggung jawab dan sikap yang memberikan timbal balik kepada perusahaan, sebagai contoh konsumen merekomendasikan kepada pembeli lainnya. Pendapat ini searah dengan kajian yang telah dilaksanakan olek Widjaja (2016) mengenai kepuasan terhadap loyalitas pelanggan pada PT. Fuboru Indonesia mendapatkan hasil jika customer satisfaction berpengaruh secara signifikan terhadap customer loyalty. Konsumen yang merasakan kepuaasan terhadap product maupun jasa yang dipergunakannya secara otomotis akan menggunakannya kembali produk yang ditawarkannya. Kepuasan pelanggan menumbuhkan loyalnya konsumen kepada product atau jasa yang ditawarkan sehingga berhasil menimbulkan loyalitas pelanggan. Ketidakpuasan pelanggan terjadi karena layanan internet yang kadang off mendadak. Hal tersebut menyebabkan pelanggan merasa kecewa dan memilih penawaran internet dari perusahaan lain. Kepuasan pelanggan mencerminkan sikap profesional perusahaan. Oleh karena itu, perusahaan harus meningkatkan kepuasan pelanggan guna meningkatkan loyalitas pelanggan yang berdampak pada laba perusahaan. Sumbangan pengaruh langsung relationship marketing $\left(\mathrm{X}_{1}\right)$ terhadap customer loyalty $(\mathrm{Y})$ lebih besar dibandingkan dengan pengaruh tidak langsung relationship marketing $\left(\mathrm{X}_{1}\right)$ terhadap customer loyalty $(\mathrm{Y})$ melalui customer satisfaction $\left(\mathrm{X}_{2}\right)$. Hal tersebut dikarenakan perusahaan yang melakukan relationship marketing jangka panjang akan memperlakukan pelanggan dengan baik dan profesional dalam melayani sehingga hal tersebut akan meningkatkan loyalitas pelanggan secara langsung. Apabila relationship marketing terjadi maka pelanggan akan merasa puas dan melakukan pembelian ulang sehingga terjadi kesetiaan yang berujung pada loyalitas pelanggan. Hal ini memberikan implikasi bahwa kepuasan pelanggan mencerminkan profesional kerja perusahaan dalam melayani pelanggan. Ketidakpuasan pelanggan dapat menyebabkan berbagai dampak yang merugikan perusahaan. Oleh karena itu, perusahaan perlu melakukan upaya lain diantaranya meningkatkan pelayanan 
yang diberikan, cepat merespon masalah pelanggan yang berkaitan dengan gangguan internet dan meningkatkan keramahtamahan karyawan terhadap pelanggan yang datang ke kantor.

Hasil penelitian yang menunjukkan $\mathrm{X}_{1}$ berpengaruh secara positif dan signifikan terhadap terhadap $\mathrm{X}_{2}$ Indihome pada PT. Telkom Indonesia Tbk Datel Singaraja. Hal tersebut sejalan dengan teori yang disampaikan oleh Hasan (2013:712-714) menjelaskan jika variable hubungan pemasaran mimiliki pengaruh positif ke customer satisfaction dengan indikasi yang dirasakan paling tidak sama dari yang diharapkan. Pendapat tersebut searah dari penelitian Widjaja (2016) mengenai relationship marketing terhadap kepuasan pelanggan pada PT. Fuboru Indonesia dengan menunjukkan perolehan jika relationship marketing berpengaruh secara signifikan terhadap customer satisfaction. Hubungan marketing yang dilakukan oleh industry mampu menaikkan customer satisfaction dalam jangka panjang sehingga mampu meningkatkan laba industri. Oleh karenanya, industry harus mampu memperhatikan variabel relationship marketing dan kepuasan pelanggan untuk mencapai target penjualan yang ingin dicapai. Hal ini memberikan implikasi bahwa relationship marketing memiliki peranan penting dalam meningkatkan kepuasan pelanggan. Kedua variabel ini terkait satu sama lain sehingga perusahaan perlu melakukan upaya perbaikan sehingga mampu bersaing dan meningkatkan loyalitas pelanggan.

Hasil penelitian menunjukkan bahwa variabel relationship marketing $\left(\mathrm{X}_{1}\right)$ berpengaruh secara positif dan signifikan terhadap loyalitas pelanggan $(\mathrm{Y})$ melalui kepuasan pelanggan $\left(\mathrm{X}_{2}\right)$ Indihome pada PT. Telkom Indonesia, Datel Singaraja. Hal tersebut sejalan dengan Hasan (2013: 108-109) menyatakan bahwa setiap perusahaan harus memiliki strategi bisnis untuk dapat memperoleh keuntungan. Pelaksanaannya ketika menyusun strategi untuk bersaing dengan pasar dan merencanakan cara untuk bertahan dalam persaingan bisnis. Taktik yang diperlukan dalam mendukung sumber dayaa yang kuat untuk menciptakan dan mewujudkan kepuasan pelanggan dan pada akhirnya berlanjut pada loyalitas pelanggan. Pendapat tersebut sejalan dengan penelitian Widjaja (2016) mengenai pengaruh relationship marketing terhadap loyalitas pelanggan melalui kepuasan pelanggan pada PT. Fuboru Indonesia di Surabaya, menunjukan bahwa customer satisfaction memiliki hubungan yang kuat terhadap hubungan pemasaran dan loyalitas pelanggan dan hubungan antara relationship marketing dan loyalitas pelanggan secara langsung lebih kuat karena tujuan utama relationship marketing di perusahaan tersebut. Terjadinya fluktuasi angka penggunaan Indihome pada PT. Telkom Indonesia Tbk Datel Singaraja. Hal ini disebabkan karena ketidakpuasan pelanggan terhadap pelayanan dalam penanganan keluhan. Oleh karena itu, perusahaan sangat perlu melakukan evaluasi sehingga terhadap ketidakpuasan yang terjadi sehingga relationship marketing dapat dilakukan secara optimal untuk meningkatkan loyalitas pelanggan. Hal ini memberikan implikasi bahwa pelanggan yang memiliki hubungan baik (relationship) dan merasa puas terhadap layanan internet yang ditawarkan maka akan mampu meningkatkan loyalitas pelanggan. Upaya peningkatan berkaitan dengan relationship marketing dan kepuasan pelanggan sangat perlu dilakukan. Oleh karena itu, perusahaan perlu membuat kebijakan-kebijakan baru untuk meningkatkan loyalitas pelanggan sehingga tujuan perusahaan tercapai.

\section{Simpulan dan Saran}

Hasil dan pengkajian yang diakukan, mendapatkan beberapa kesimpulan yakni: (1) Relationship marketing berpengaruh secara positif dan signifikan terhadap loyalitas pelangan Indhome pada PT. Telkom Indonesia, Datel Singaraja. (2) customer satisfaction berpengaruh secara positive dan signifikan terhadap customer loyalty Indihome pada PT. Telkom Indonesia Tbk Datel Singaraja. (3) Relationship marketing berpengaruh secara positif dan signifikan terhadap customer satisfaction Indihome pada PT. Telkom IndonesiaTbk Datel Singaraja. (4) Relationship marketing berpengaruh secara positif dan signifikan terhadap loyalitas pelanggan melalui kepuasan pelanggan Indihome pada PT. Telkom Indonesia Tbk Datel Singaraja.

Berdasarkan dari simpulan tersebut, bahwa pentingnya untuk mengajukan beberapa saran, yakni: (1) Untuk pihak dari perusahaan PT. Telkom Indonesia Tbk Datel Singaraja, agar meningkatkan loyalitas pelanggan melalui relationship marketing dan kepuasan pelanggan. 
Peningkatan loyalitas pelanggan ini dapat dilakukan dengan menjalin hubungan baik dengan pelanggan, mengevaluasi keluhan yang masuk dan meningkatkan pelayanan secara profesional. Pelanggan yang merasa puas akan melakukan pembelian ulang sehingga akan menimbulkan kesetiaan yang berujung pada loyalitas pelanggan. (2) Bagi peneliti selanjutnya, khususnya yang tertarik dan berminat untuk mendalami tentang relationship marketing dan kepuasan pelanggan terhadap loyalitas pelanggan diharapkan untuk mengembangkan penelitian ini dengan menambahkan sampel yang lebih luas agar dapat menguji variabel lainnya yang diduga kuat dapat memengaruhi loyalitas pelanggan.

\section{Daftar Pustaka}

Ariawan, Deny. 2001. Analisis Pengembangan Model Relationship Marketing Rumah Sakit. Tesis. Semarang: Universitas Diponegoro.

Buttle, Francis. 2004. Customer Relationship Management (Management Hubungan Pelanggan) Concept and Tools. Bayumedia. Malang.

Farizka, Achmad. 2011. Pengaruh Relationship Marketing Dan Creating Customer Value Terhadap Kepuasan Pelanggan Dan Loyalitas Pelanggan Mobil Honda Di Kota Malang. Malang: Pascasarjana Fakultas Ekonomi Dan Bisnis Universitas Brawijaya.

Ferdinand. 2002. Metode Penelitian Manajemen: Pedoman penelitian untuk Skripsi, Tesis, dan Desertasi IImu Manajemen, Semarang: Badan Penerbit Universitas Diponegoro.

Hasan, Ali. (2013). Marketing Dan Kasus-kasus Pilihan. Yogyakarta: CAPS.

Hermawan Kartajaya. 2003. Marketing In Venus. Jakarta: Gramedia Pustaka Utama.

Hindarto, Peter Daud. 2013. Hubungan Relationship Marketing Dengan Loyalitas Pelanggan Ritel. Jurnal JIBEKA Volume 7, No 3 Agusus 2013: 41-46.

Husodho, Widyaningrat Resti. 2015, Pengaruh Kepuasan Pelanggan Terhadap Loyalitas Pelanggan Pada Obyek Wisata Dumilah Water Park Madiun. Jurnal IImiah Ekonomi, Vol. 3, No. 2.

Martini, Luh Kadek Budi (2013). Relationship Marketing, Customer Satisfaction, Customer Commitment dan Customer Loyalty (Studi Pada Sebuah Bank Nasional Di Depansar). Buletin Studi Ekonomi, Vol. 18, No. 1, Februari 2013.

Romero, Maria José Miquel, Eva María Caplliure-Giner, and Consolación Adame-Sánchez. 2014. Relationship Marketing Management: Its Importance in Private Label Extension. Journal of Business Research Vol 67, pp 667-672.

Sangadji, Etta Mamang \& Sopiah. (2013). Perilaku Konsumen - Pendekatan Praktis disertai Himpunan Jurnal Penelitian. Yogyakarta: ANDI.

Sugiyono. 2007. Metode Penelitian Kuantitatif Kualitatif dan R\&D. Bandung: Alfabeta.

2014. Metode Penelitian Pendidikan Pendekatan Kuantitatif, Kualitatif, dan R\&D. Bandung: Alfabeta.

T. Velnampy, PS Sivesan. 2012. Customer Relationship Marketing and Customer Satisfaction : A Studi on Mobile Service Providing Compainess In Srilangka. Journal of Business Org 
Tjiptono, Fandi. 2011. Strategi Pemasaran., Edisi kedua, Cetakan pertama. Yogyakarta : Andi Offset.

Widjaja, Clarisha Octavia. 2016. Pengaruh Relationship Marketing Terhadap Customer loyalty dan Customer Satisfaction sebagai variabel intervening pada PT. Fuboru Indonesia di Surabaya. Jurnal Manajemen Pemasaran. Vol 10, No2.

Wiryanto. 2004. Pengantar IImu Komunikasi. Jakarta: PT. Grasindo.

https://www.cnbcindonesia.com/ (diakses tanggal 14 januari 2020)

https://www.topbrand-award.com/ (diakses tanggal 22 april 2020) 